\title{
Effect of microfiltration concentration factor on serum protein removal from skim milk using spiral-wound polymeric membranes ${ }^{1}$
}

\author{
S. L. Beckman and D. M. Barbano ${ }^{2}$ \\ Northeast Dairy Foods Research Center, Department of Food Science, Cornell University, Ithaca, NY 14853
}

\begin{abstract}
Our objective was to determine the effect of concentration factor $(\mathrm{CF})$ on the removal of serum protein (SP) from skim milk during microfiltration (MF) at $50^{\circ} \mathrm{C}$ using a $0.3-\mu \mathrm{m}$-pore-size spiral-wound ( $\mathrm{SW}$ ) polymeric polyvinylidene fluoride (PVDF) membrane. Pasteurized $\left(72^{\circ} \mathrm{C}\right.$ for $\left.16 \mathrm{~s}\right)$ skim milk was $\mathrm{MF}\left(50^{\circ} \mathrm{C}\right)$ at $3 \mathrm{CF}(1.50,2.25$, and $3.00 \times)$, each on a separate day of processing starting with skim milk. Two phases of MF were used at each $\mathrm{CF}$, with an initial startup-stabilization phase (40 min in full recycle mode) to achieve the desired CF, followed by a steady-state phase (90-min feed-and-bleed with recycle) where data was collected. The experiment was replicated 3 times, and SP removal from skim milk was quantified at each CF. System pressures, flow rates, $\mathrm{CF}$, and fluxes were monitored during the 90-min run. Permeate flux increased $(12.8,15.3$, and $19.0 \mathrm{~kg} / \mathrm{m}^{2}$ per hour) with decreasing CF from 3.00 to $1.50 \times$, whereas fouled water flux did not differ among CF, indicating that the effect of membrane fouling on hydraulic resistance of the membrane was similar at all CF. However, the CF used when microfiltering skim milk $\left(50^{\circ} \mathrm{C}\right)$ with a $0.3-\mu \mathrm{m}$ polymeric SW PVDF membrane did affect the percentage of SP removed. As CF increased from 1.50 to $3.00 \times$, the percentage of SP removed from skim milk increased from 10.56 to $35.57 \%$, in a single stage bleed-and-feed MF system. Percentage SP removal from skim milk was lower than the theoretical value. Rejection of SP during MF of skim milk with SW PVDF membranes was caused by fouling of the membrane, not by the membrane itself and differences in the foulant characteristic among $\mathrm{CF}$ influenced SP rejection more than it influenced hydraulic resistance. We hypothesize that differences in the conditions near the surface of the membrane and within the pores during the first few minutes of processing,
\end{abstract}

Received February 2, 2013.

Accepted May 23, 2013.

${ }^{1}$ Use of names, names of ingredients, and identification of specific models of equipment is for scientific clarity and does not constitute any endorsement of product by the authors, Cornell University, or the Northeast Dairy Foods Research Center.

${ }^{2}$ Corresponding author: dmb37@cornell.edu when casein micelles pass through the membrane, influenced the rejection of SP because more pore size narrowing and plugging occurred at low $\mathrm{CF}$ than at high $\mathrm{CF}$ due to a slower rate of gel layer formation at low $\mathrm{CF}$. It is possible that percentage removal of SP from skim milk at $50^{\circ} \mathrm{C}$ could be improved by optimization of the membrane pore size, feed solution composition and concentration, and controlling the rate of formation of the concentration polarization-derived gel layer at the surface of the membrane during the first few minutes of processing.

Key words: microfiltration, concentration factor, serum protein, spiral-wound membrane

\section{INTRODUCTION}

Cross-flow microfiltration (MF) of skim milk is a pressure-driven membrane separation that can be used to separate serum proteins (SP) from $\mathrm{CN}$ proteins in skim milk. Pore sizes of membranes used for MF range from 0.1 to $5.0 \mu \mathrm{m}$, depending on the application (Cheryan, 1998). Casein micelles (0.02 to $0.40 \mu \mathrm{m}$ in diameter) are in colloidal suspension in milk, and are approximately 100 times larger than SP (0.003 to $0.010 \mu \mathrm{m}$ ), which are soluble in milk (Walstra et al., 2006). Retentates produced during MF of skim milk using a membrane with a pore size of 0.1 to 0.3 $\mu \mathrm{m}$ contain higher concentrations of $\mathrm{CN}$ micelles and other suspended particles, which are larger than the maximum membrane pore size. The $\mathrm{CN}$-rich retentates, often called micellar casein concentrates (MCC), can be used in myriad of products including cheese (Nelson and Barbano, 2005), or other food and beverage products.

Membrane materials commonly used to microfilter skim milk to create MCC include ceramic (i.e., inorganic) and polymeric organic materials. Ceramic MF membranes used for the production of MCC have been studied (Zulewska et al., 2009; Hurt et al., 2010), and the advantages of their use compared with polymeric MF membranes include longer life and greater resistance to cleaning chemicals and higher temperatures (Cheryan, 1998). The most common configuration of polymeric membranes used by the dairy industry in 
North America is spiral-wound (SW) but other configurations (e.g., tubular, hollow fiber, and flat sheet) are possible. Spiral-wound polymeric MF membranes have the advantage of being less expensive to purchase (Cheryan, 1998), and SW membrane technology is familiar to the dairy industry, as it has been used since the 1970s for UF of cheese whey (Maubois, 1980). Most published research on MCC manufacture using MF has focused on ceramic membranes (Saboya and Maubois, 2000; Zulewska et al., 2009; Hurt et al., 2010) because of their recognized ability to separate SP from $\mathrm{CN}$ in skim milk. Ceramic membranes have a narrower pore size distribution than polymeric membranes (Brans et al., 2004), which gives ceramic membranes an enhanced ability to retain particles with diameters greater than a given pore size.

Currently, no commercial sales or utilization of MCC and serum protein concentrate exist as functional protein ingredients in foods. Experimentation with the manufacture and characterization of the functional properties of these products and comparison with similar chemically precipitated casein products or whey protein products will establish any economic or functional advantages of these dairy protein ingredients. Beliciu et al. (2012) and Sauer and Moraru (2012) had demonstrated that MCC may have advantages in retorted shelf-stable high-protein nutritional beverages. Opportunities may exist to use serum protein concentrate for protein beverage fortification due to their better clarity (Evans et al., 2009, 2010) and cleaner flavor profile than whey protein concentrates (Evans et al., 2009, 2010; Jervis et al., 2012; Campbell et al., 2013) for possible use in clear, low-pH, shelf-stable beverages. Clearly, the cost of ceramic membranes and the energy use are both high and have been concerns, making dairy processors cautious about investing in this technology even when their flux of $\geq 54 \mathrm{~kg} / \mathrm{m}^{2}$ per hour is attractive (Hurt et al., 2010). The cost of polymer MF membrane systems is much lower than ceramic systems (Cheryan, 1998), but their propensity to foul and exhibit low flux compared with ceramic MF membranes (Zulewska et al., 2009) is a concern and reduces their cost advantage. Low permeate flux (6 to $17 \mathrm{~kg} / \mathrm{m}^{2}$ per hour) during MF (with SW membranes) of skim milk have been reported (Lawrence et al., 2008; Zulewska et al., 2009; Beckman et al., 2010). Fouling of ceramic membranes during skim milk MF is minimized by high cross-flow velocities (e.g., 5 to $7 \mathrm{~m} / \mathrm{s}$ ) and a uniform transmembrane pressure (TMP; Saboya and Maubois, 2000). Not all configurations of ceramic membranes produce the same percent SP removal, and a recent study of Isoflux ceramic membranes (Technologies Avancees et Membranes Industrielles Nyons, France) reported a substantially lower (ca. 70\%) SP removal for a 3 -stage, $3.00 \times$ concentration process at $50^{\circ} \mathrm{C}$ (Adams and Barbano, 2013). Spiral-wound MF membranes operate at lower (e.g., $<2 \mathrm{~m} / \mathrm{s}$ ) cross-flow velocities (Lawrence et al., 2008) and typically do not operate with a uniform TMP (Zulewska et al., 2009; Beckman et al., 2010), leading to much lower flux than that of ceramic membranes.

One of the largest disadvantages of SW polymeric MF membranes is the low efficiency of SP removal from skim milk. Zulewska et al. (2009) reported single-stage SP removal rates from skim milk at $50^{\circ} \mathrm{C}$ at $3.00 \times$ concentration factor (CF) of 64,61 , and $39 \%$ for ceramic uniform-TMP (UTP), ceramic graded-permeability, and SW polymeric membranes, respectively. For an SW MF system, Beckman et al. (2010) reported about a $70 \%$ SP removal from skim milk in a 3 -stage $3.00 \times$ concentration process at $50^{\circ} \mathrm{C}$ compared with an SP removal of about 98\% with UTP (Hurt et al., 2010) and $97 \%$ with graded-permeability ceramic membranes (J. Zulewska, Faculty of Food Science, University of Warmia and Mazury, Olsztyn, Poland, personal communication). In the report by Beckman et al. (2010), it was observed that flux increased with decreasing $\mathrm{CF}$ and we hypothesize that SP removal with SW membranes may be higher when the SW system is operated at lower CF, higher flux, and with less concentration polarization fouling.

Increasing the SP removal performance of SW polymeric MF would improve the chances of widespread implementation of this technology in the dairy industry and potentially increase the utilization of milk proteins in foods. An improved understanding of fouling of SW MF membranes and development of methods to improve polymeric membrane performance for separation of CN and SP from skim milk are needed. Our objective was to determine the effect of different MF CF (1.50, 2.25 , and $3.00 \times)$ on SP removal from skim milk, and fouling of polymeric polyvinylidene fluoride (PVDF) $\mathrm{SW} 0.3-\mu \mathrm{m}$ MF membranes at $50^{\circ} \mathrm{C}$.

\section{MATERIALS AND METHODS}

\section{Experimental Design and Statistical Analysis}

On d 1 of processing, raw whole milk was centrifugally $\left(4^{\circ} \mathrm{C}\right.$; model 372 Airtight; DeLaval Separator Co., Poughkeepsie, NY) separated at 5,000 $\times g$ into skim milk and cream. The skim milk was pasteurized $\left(72^{\circ} \mathrm{C}\right.$ for $\left.16 \mathrm{~s}\right)$ and stored at $4^{\circ} \mathrm{C}$. On d 2,3 , and 4 , the pasteurized skim milk was $\mathrm{MF}$ at $50^{\circ} \mathrm{C}$ using a $0.3-\mu \mathrm{m}$-nominal-pore-size SW polymeric PVDF membrane, using 1 of $3 \mathrm{CF}(1.50,2.25$, or $3.00 \times)$ on each of the days. On each day of filtration, 2 phases of the MF processing were run: startup-stabilization (about 
$40 \mathrm{~min}$ ) and steady-state processing phase (about 90 min), each using skim milk as the feed material. Flux ( $\mathrm{kg}$ of permeate $/ \mathrm{m}^{2}$ per hour) and CF \{[permeate $(\mathrm{kg})$ + retentate $(\mathrm{kg})] /$ retentate $(\mathrm{kg})\}$ were measured at 5-min intervals during the startup-stabilization phase until the desired $\mathrm{CF}$ was achieved. The steady-state processing phase lasted 90 min during which flux and $\mathrm{CF}$ were measured every 5 min $(2.25$ and $3.00 \times \mathrm{CF})$ or $2.5 \mathrm{~min}(1.50 \times \mathrm{CF})$. Samples of permeate and retentate were taken during the run to determine the amount of SP being removed. The experiment was replicated in 3 different weeks using different lots of whole milk. The order of the CF among d 2, 3, and 4 was rotated from one replicate to the next to achieve a balanced design with respect to the day on which each $\mathrm{CF}$ was produced.

To determine if the CF used during MF of skim milk at $50^{\circ} \mathrm{C}$ influenced the observed operational parameters, mean flux, and composition of the composite permeates and retentates, statistical analysis of the data was done using PROC GLM of SAS (version 9.3, 2011; SAS Institute Inc., Cary, NC). The GLM was as follows: dependent variable $=$ target $\mathrm{CF}+$ replicate + error, with target $\mathrm{CF}$ and replicate as category variables. Milk permeate fluxes and true protein (TP) content of permeates and retentates were measured throughout the steady-state processing and the data were analyzed for change over time using the data analysis tool-pack regression function in Microsoft Excel (Excel 2010; Microsoft Corp., Redmond, WA) to determine if the change in slope with time was different $(P<0.05)$ than zero.

\section{Separation and Pasteurization of Milk}

On the first day of each replicate, 1 lot of raw whole milk (approximately 2,145 kg) from the Cornell University Dairy (Ithaca, NY) was separated (model 372 Airtight; DeLaval Separator Co., Poughkeepsie, NY) into skim milk and cream at $4^{\circ} \mathrm{C}$. The raw skim milk was pasteurized with a plate heat exchanger consisting of 3 sections: regeneration, heating, and cooling (model 080-S; AGC Engineering Inc., Manassas, VA) at an average of $72.5 \pm 0.1^{\circ} \mathrm{C}$ and a holding time of $16 \mathrm{~s}$. The pasteurized skim milk was pumped into a jacketed stainless steel tank where it was held without agitation at $<4^{\circ} \mathrm{C}$ for use during the subsequent 3 processing days. Approximately $560 \mathrm{~kg}$ of skim milk to be used each day for MF was pumped out of the tank after agitating the tank for $10 \mathrm{~min}$. A sample of pasteurized skim milk was taken on d 1 for chemical analysis by agitating the skim milk in the large jacketed tank for $\geq 10$ min and using a sanitized sampling dipper.

\section{MF of Skim Milk}

A diagram of the SW MF system used in this experiment is shown in Figure 1. On d 1 in each of the 3 processing weeks, the MF system was cleaned using the "long-clean" procedure used by Beckman et al. (2010). Before MF of skim milk on d 2,3, and 4, the membrane was sanitized and a starting water flux before milk processing was determined, following the "short-clean" procedure from Beckman et al. (2010). The membrane was drained of storage solution, flushed, and rinsed with $<24^{\circ} \mathrm{C}$ reverse osmosis ( $\left.\mathbf{R O}\right)$ water, and then sanitized with a solution of Ultrasil 110 (Ecolab Inc., St. Paul, $\mathrm{MN})$ liquid alkaline membrane cleaner $(0.39 \% \mathrm{vol} / \mathrm{vol})$ and XY-12 (Ecolab Inc.) liquid sanitizer $(0.15 \% \mathrm{vol} /$ vol) in $\mathrm{RO}$ water $\left(<24^{\circ} \mathrm{C}\right)$ to a $\mathrm{pH}$ of 11.2 to 11.4 and a chlorine level of 150 to $180 \mathrm{mg} / \mathrm{kg}$. The sanitizer was circulated through the MF system for $10 \mathrm{~min}$ before being drained and flushed out with $<24^{\circ} \mathrm{C} \mathrm{RO}$ water to neutral pH. A starting water flux was measured (Beckman et al., 2010) and the MF system was then stopped, valves closed, and left standing with $\mathrm{RO}$ water filling the system until the system was ready to be fed with $50^{\circ} \mathrm{C}$ skim milk.

Microfiltration of skim milk for each replicate occurred sequentially on $3 \mathrm{~d}$, using a different $\mathrm{CF}$ on each day $(1.50,2.25$, and $3.00 \times$, respectively). For each $\mathrm{CF}$ within a day, there were 2 phases of processing: startup-stabilization (about $40 \mathrm{~min}$ ) and steady-state processing phases (about $90 \mathrm{~min}$ ). Each phase began with skim milk heated to $50^{\circ} \mathrm{C}$. On the first day of $\mathrm{MF}$, approximately $260 \mathrm{~kg}$ of $4^{\circ} \mathrm{C}$ pasteurized skim milk was quantitatively transferred into a feed vat (Figure 1) and was heated to $50^{\circ} \mathrm{C}$ using a pump and plate heat exchanger. The MF system was full of water and air was pushed out of the system with water. The SW MF system startup-stabilization phase was as follows: the permeate exit valve was closed, retentate bleed valve opened, recirculation loop closed at the return line to the recirculation pump (Figure 1), and the feed pump was turned on, feeding the retentate side of the membrane with $50^{\circ} \mathrm{C}$ skim milk, clearing the $\mathrm{RO}$ water out, and not allowing any permeation of the membrane. After skim milk exited the retentate hose, the valve in the recirculation loop was opened and the recirculation pump was turned on to set the retentate pressure at the inlet $\left(\mathbf{R} \mathbf{p}_{\mathbf{i}}\right)$ at the correct pressure for the run, as established with water before skim milk. Next, the permeate exit valve was slowly opened to allow system pressures to balance and to begin MF. The retentate bleed valve was adjusted to give the correct $\mathrm{CF}$, and the system pressures were maintained. Flux and $\mathrm{CF}$ measurements commenced once permeate exited the system. The $50^{\circ} \mathrm{C}$ skim milk was $\mathrm{MF}$ using a single 


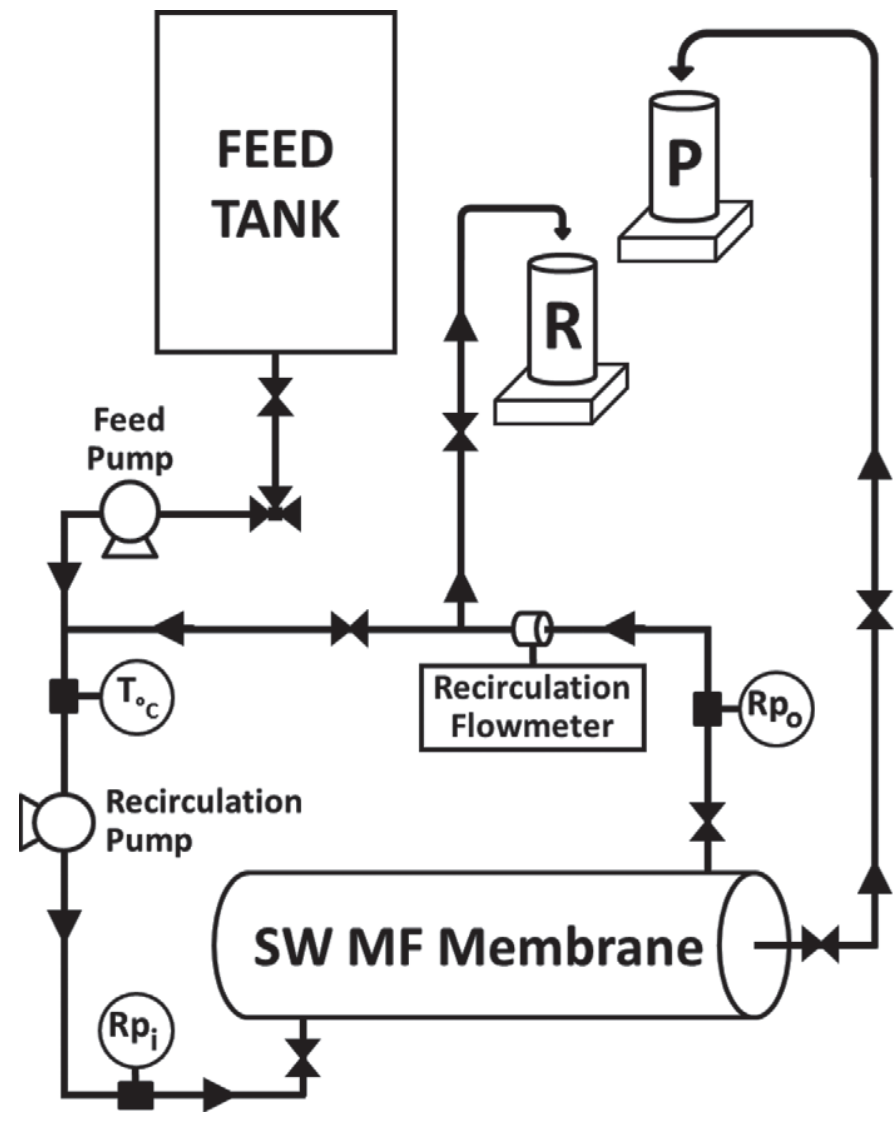

Figure 1. The polyvinylidene fluoride spiral-wound microfiltration (SW MF) system used during the microfiltration of skim milk $\left(50^{\circ} \mathrm{C}\right)$ at 3 concentration factors: $1.50,2.25$, and $3.00 \times$. Measurements in the system during processing included temperature $\left(\mathrm{T}_{{ }^{\circ}}\right)$, retentate pressure inlet $\left(R p_{i}\right)$, retentate pressure outlet $\left(R p_{o}\right)$, and recirculation flow rate (recirculation flowmeter; $\mathrm{L} / \mathrm{min}$ ). Retentate $(\mathrm{R})$ and permeate (P) were collected and weighed during processing.

SW polymeric MF membrane (model FG7838-OSx-S, 0.3- $\mu \mathrm{m}$ pore size PVDF, 20.5- $\mathrm{m}^{2}$ surface area, 1.09-mm spacer, 96.5-cm length $\times$ 19.8-cm diameter; ParkerHannifin, Process Advanced Filtration Division, Tell City, IN) at the target $\mathrm{CF}$ for $40 \mathrm{~min}$ in total recirculation mode, with a measurement of flux and CF every 5 min. This membrane element has had limited use and had only been used previously to process skim milk and MF permeate from milk as described in the papers by Beckman et al. (2010) and Zulewska and Barbano (2013). The purpose of the startup-stabilization phase was to flush the water out of the system and to achieve a retentate composition to near steady state before the steady-state processing phase. Permeate and retentate were recirculated to the feed vat for $40 \mathrm{~min}$ and then allowed to flow to the drain to reduce the volume of skim milk in the feed vat to near zero. Next, more pasteurized skim milk (approximately $300 \mathrm{~kg}$ ) at $50^{\circ} \mathrm{C}$ was weighed into to the feed vat and $\mathrm{MF}$ at the target $\mathrm{CF}$ for the steady-state processing phase without stopping the system. During the steady-state processing phase (90 min), flux and CF were measured, along with collection of permeate and retentate samples, approximately every $2.5 \mathrm{~min}$ for $\mathrm{CF}=1.50 \times$ and $5 \mathrm{~min}$ for $\mathrm{CF}=2.25$ and $3.00 \times$. The different interval of measurement for $\mathrm{CF}=1.50 \times$ compared with $\mathrm{CF}=2.25$ and $3.00 \times$ was due to the high rate of flow of permeate and retentate exiting the system at lower CF. After weighing and sampling the collected permeate and retentate, both portions were added back to the feed vat to maintain constant feed level and composition throughout the run. At the end of the 90-min steady-state processing phase, the MF system was drained, shut down, and cleaned to prepare for d 2 of MF. At the end of the run each day, the membrane was given a "long clean," as described by Beckman et al. (2010). A fouled water flux and ending water flux after cleaning were obtained during the long clean to determine the extent of fouling on the membrane and to ensure the water permeability of the membrane was restored to the prerun condition.

Pressures $(\mathrm{kPa})$ in the MF system (Figure 1), measured by digital pressure gauges (model PI2094; IFM Efector Inc., Exton, PA) were recorded each time the flux was measured, and included $\mathrm{Rp}_{\mathrm{i}}$ and retentate pressure at the outlet $\left(\mathbf{R p}_{\mathbf{o}}\right)$. Permeate pressure at the outlet was not measured and was assumed to be $0 \mathrm{kPa}$ because the permeate exit tube was open to the atmosphere. The difference in pressure $(\Delta \mathbf{P})$ between the retentate inlet and retentate outlet $\left[\Delta \mathrm{P}=\left(\mathrm{Rp}_{\mathrm{i}}+\right.\right.$ $\left.\mathrm{Rp}_{\mathrm{o}}\right) / 2$ ] of the membrane was kept constant at $100 \mathrm{kPa}$ (14.5 psi) for all CF used. A digital magnetic mass flow meter (model AM204DH; Yokogawa Electronic Corp., Tokyo, Japan) was used to measure the recirculation loop flow rate $(\mathrm{L} / \mathrm{min})$.

\section{Analyses of Milk, Retentate, and Permeate}

Retentate and permeate samples collected at 5-min $(2.25$ and $3.00 \times \mathrm{CF})$ or 2.5 -min $(1.50 \times \mathrm{CF})$ intervals during the steady-state processing phase were combined into a weighted composite retentate and permeate sample, respectively. For example, the calculated mass of liquid permeate added to the composite from each fraction of permeate collected was based on the mass $(\mathrm{kg})$ of the permeate fraction collected during the 5 - or 2.5-min intervals divided by the total mass $(\mathrm{kg})$ of permeate collected during the entire 90-min steadystate processing phase. Composite retentate samples were created using the same method. Composites were created so that representative samples of steady-state phase permeate and retentate could be analyzed for SP removal. 
Pasteurized skim milk, composite retentate, and composite permeate were analyzed for protein, fat, and TS content. Protein content (\%) was measured using total $\mathrm{N}$ ( TN), noncasein N (NCN), and NPN content by Kjeldahl methods (AOAC International, 2000; methods 991.2, 33.2.11; 998.05, 33.2.64; and 991.21, 33.2.12, respectively). Fat content was measured by Mojonnier ether extraction (AOAC International, 2000; method 989.05, 33.2.26). Total solids were measured using the forced-air oven drying method (AOAC International, 2000; method 990.20, 33.2.44). True protein was calculated by subtracting NPN from TN and multiplying the difference by 6.38 . Casein content of skim milk and MF permeate was calculated as TN minus NCN and serum protein was calculated as TP minus $\mathrm{CN}$ and multiplying the difference by 6.38 . Serum protein in the permeate portion of the skim milk (\%) was calculated by dividing $\mathrm{SP}$ in the skim milk by SP in the permeate portion of the skim milk multiplied by 100 , where the permeate portion of skim milk is considered as follows: $100 \mathrm{~kg}$ minus weight of casein plus fat in $100 \mathrm{~kg}$ of skim milk. The permeate portion of skim milk represents only the components of skim milk that would be available to flow freely through the membrane. Serum protein removal (\%) from skim milk was calculated by dividing SP $(\mathrm{kg})$ in composite permeate by $\mathrm{SP}(\mathrm{kg})$ in skim milk and multiplying by $100 \%$, using the Kjeldahl nitrogen analyses above and recorded processing data.

Pasteurized skim milk, composite retentate, composite permeate, and individual fractions of retentate and permeate from the data-collection stage of processing were all analyzed using an infrared spectrophotometer [LactoScope Fourier transform infrared (FTIR); Delta Instruments BV, Drachten, the Netherlands] for fat, anhydrous lactose, and TP content (Kaylegian et al., 2006). To reduce the effect of any day-to-day instrument variation, all infrared measurements were analyzed in 1 batch on the same day $(\mathrm{d}=4)$ of the replicate. Hunter color value L (lightness) of composite permeate was analyzed $\left(25^{\circ} \mathrm{C}\right)$ using a Macbeth Color-Eye spectrophotometer (model 2020; Kollmorgen Instrument Corp., Newburgh, NY) to determine if differences in opacity of permeate existed among $\mathrm{CF}$ that might reflect differences in $\mathrm{CN}$ passage through the membrane.

\section{RESULTS AND DISCUSSION}

\section{Milk Processing Parameters and Flux}

Operational Parameters. The average $(\mathrm{n}=3) \mathrm{SW}$ MF system operational parameters recorded during steady-state processing of skim milk are shown in Table 1. No differences in the $\Delta \mathrm{P}$ (i.e., pressure drop from inlet to outlet of the SW MF membrane), the $\mathrm{Rp}_{\mathrm{i}}$, and
$\mathrm{Rp}_{\mathrm{o}}$ among the $3 \mathrm{CF}$ were detected $(P>0.05$; Table 1$)$. The $\Delta \mathrm{P}$ were similar to values reported by Zulewska et al. (2009) and Beckman et al. (2010) for MF of skim milk $\left(50^{\circ} \mathrm{C}\right)$ at $\mathrm{CF} 3.00 \times$ using the same membrane system and membrane. However, the average $\mathrm{Rp}_{\mathrm{i}}$ reported by Zulewska et al. (2009) and Beckman et al. (2010; 131.3 and $132.4 \mathrm{kPa}$, respectively) were higher than what we observed for all $3 \mathrm{CF}$ used (Table 1). A higher $\mathrm{Rp}_{\mathrm{i}}$ while maintaining a similar $\Delta \mathrm{P}$ (about $100 \mathrm{kPa}$ ) required lower $R p_{o}$ values, according to the equation for calculating $\Delta \mathrm{P}\left[\Delta \mathrm{P}=\left(\mathrm{Rp}_{\mathrm{i}}+\mathrm{R} \mathrm{p}_{\mathrm{o}}\right) / 2\right]$, which was what occurred in the previous work of Zulewska et al. (2009) and Beckman et al. (2010). The average difference between $R p_{i}$ and $R p_{o}$ was smaller in the present study $(30.2 \mathrm{kPa})$ than for Zulewska et al. (2009; 70.7 $\mathrm{kPa})$ or Beckman et al. $(2010 ; 65.1 \mathrm{kPa})$. A smaller difference between the TMP from the inlet side of the membrane and the outlet side of the membrane is desirable. Lawrence et al. (2008) demonstrated that as TMP increases, the rejection of all milk proteins increases when microfiltering skim milk using SW polymeric membranes. This smaller difference between $\mathrm{Rp}_{\mathrm{i}}$ and $\mathrm{Rp}_{\mathrm{o}}$ in the present study compared with the previous studies was achieved by reducing the pipe inner diameter from 35 to $22 \mathrm{~mm}$ (i.e., increasing the resistance to recirculation loop flow) between the recirculation loop flow sensor and the recirculation pump (Figure 1).

Average $(\mathrm{n}=3)$ retentate and permeate removal rates $(\mathrm{kg} / \mathrm{min})$ decreased $(P<0.05)$ with increasing $\mathrm{CF}$ (Table 1). Retentate removal rate decreased from $13.2 \mathrm{~kg} / \mathrm{min}$ at $1.50 \times$ to $2.1 \mathrm{~kg} / \mathrm{min}$ at $3.00 \times \mathrm{CF}$, and permeate removal rate decreased from $6.5 \mathrm{~kg} / \mathrm{min}$ at $1.50 \times$ to $4.2 \mathrm{~kg} / \mathrm{min}$ at $3.00 \times \mathrm{CF}$. The retentate removal rate was expected to show a larger decrease than permeate removal when processing at higher $\mathrm{CF}$ because the $\mathrm{CF}$ was controlled by adjusting only the retentate removal rate. Retentate recirculation flow (L/ min) decreased $(P<0.05)$ with increasing $\mathrm{CF}$ (Table 1). All recirculation flows in this experiment (Table 1) were lower than those reported by Zulewska et al. (2009) and Beckman et al. (2010) during MF of skim milk (239 and $238 \mathrm{~L} / \mathrm{min}$, respectively). The lower recirculation rates observed in the current study were caused by the smaller diameter piping being used in the retentate recirculation loop located after the retentate outlet and before the recirculation pump, as described above. Average $(\mathrm{n}=3)$ measured $\mathrm{CF}$ were different $(P$ $<0.05)$ but were near the target $\mathrm{CF}$ of $1.50,2.25$, and $3.00 \times$, respectively (Table 1 ). The CF measured during steady-state processing were near the target values because the CF were set and stabilized during the startup phase of processing.

Flux. Average $(\mathrm{n}=3)$ milk permeate flux, starting water flux, fouled water flux, and ending water flux are 
Table 1. Mean $(\mathrm{n}=3)$ operational parameters recorded during microfiltration of skim milk at 3 concentration factors $(\mathrm{CF})$ using a 0.3 - $\mu \mathrm{m}$-pore-size spiral-wound polyvinylidene fluoride membrane at $50^{\circ} \mathrm{C}$

\begin{tabular}{lcccccc}
\hline \multicolumn{7}{c}{ Operational parameter } \\
\cline { 2 - 6 } \\
\cline { 2 - 6 }
\end{tabular}

shown in Table 2. Average milk permeate flux decreased $(P<0.05)$ with increasing CF (Table 2$)$. After $10 \mathrm{~min}$ into steady-state processing, the flux at $1.50,2.25$, and $3.00 \times \mathrm{CF}$, decreased $(P<0.05) 0.16$, increased $(P<$ $0.05) 0.15$, and decreased $(P<0.05) 0.48 \mathrm{~kg} / \mathrm{m}^{2}$ per hour, respectively (Figure 2). The changes with time at 1.50 and $2.25 \times \mathrm{CF}$ were very small; however, the size of the decrease in flux at $3.00 \times$ over many hours would be of practical importance for a factory. Mean milk permeate flux at CF $3.00 \times$ (Table $2 ; 12.81 \mathrm{~kg}$ / $\mathrm{m}^{2}$ ) was slightly lower than those reported by Zulewska et al. (2009; $16.2 \mathrm{~kg} / \mathrm{m}^{2}$ per hour) and Beckman et al. $\left(2010 ; 14.4 \mathrm{~kg} / \mathrm{m}^{2}\right.$ per hour) for MF of skim milk $\left(50^{\circ} \mathrm{C}\right)$ at $\mathrm{CF}=3.00 \times$ using a $\mathrm{SW}$ polymeric $\mathrm{MF}$ membrane, but all of these are much lower than values (i.e., $54.2 \mathrm{~kg} / \mathrm{m}^{2}$ per hour) reported by Hurt et al. (2010) for ceramic UTP membranes. Higher fluxes during MF of skim milk using ceramic membranes than with SW polymeric membranes have been attributed to reduced protein fouling of the membrane, resulting from the high cross-flow velocities (e.g., 6 to $8 \mathrm{~m} / \mathrm{s}$ ), and lower TMP that are achieved in ceramic MF processes (Lawrence et al., 2008). Less fouling (i.e., lower resistance) of the membrane plus foulant and low permeate viscosity (e.g., at low CF) are expected to achieve higher flux according to Darcy's law. Permeate flux is directly proportional to the TMP and inversely proportional to the dynamic viscosity of the fluid permeating the membrane and overall hydraulic resistance (Marshall and Daufin, 1995; Le Berre and Daufin, 1996).

No difference in both clean-membrane fluxes (starting water flux and ending water flux) were detected $(P>0.05)$ among $C F$ (Table 2). Ending water fluxes were similar to starting water fluxes, which meant that membrane cleaning restored membrane permeability in preparation for each run. No difference in fouled water flux after processing was detected $(P>0.05)$ among CF (Table 2), indicating that hydraulic resistance of the fouled membrane was consistent among the $\mathrm{CF}$ used. Fouled water flux at all $3 \mathrm{CF}$ in this experiment (Table $2 ; 18.68 \mathrm{~kg} / \mathrm{m}^{2}$ per hour) were higher than values reported by Zulewska et al. $\left(2009 ; 11.5 \mathrm{~kg} / \mathrm{m}^{2}\right.$ per h) and Beckman et al. (2010; $13.9 \mathrm{~kg} / \mathrm{m}^{2}$ per h), using the same SW MF system and membrane. The degree of fouling, which is an indication of the fouling of the membrane, is calculated as follows:

Table 2. Mean $(\mathrm{n}=3)$ flux by concentration factor $(\mathrm{CF})$ during skim milk microfiltration and cleaning using a $0.3-\mu \mathrm{m}$ spiral-wound polyvinylidene fluoride membrane

\begin{tabular}{lcccc}
\hline & $\begin{array}{c}\text { Milk permeate flux } \\
\left(\mathrm{kg} / \mathrm{m}^{2} \text { per hour }\right)\end{array}$ & $\begin{array}{c}\text { Starting water flux } \\
\text { before milk } \\
\left(\mathrm{kg} / \mathrm{m}^{2} \text { per hour }\right)\end{array}$ & $\begin{array}{c}\text { Fouled water flux } \\
\left(\mathrm{kg} / \mathrm{m}^{2} \text { per hour }\right)\end{array}$ & $\begin{array}{c}\text { Ending water flux } \\
\text { after cleaning }^{4} \\
\left(\mathrm{~kg} / \mathrm{m}^{2} \text { per hour }\right)\end{array}$ \\
\hline $1.50 \times$ & $18.97^{\mathrm{a}}$ & $33.54^{\mathrm{a}}$ & $21.12^{\mathrm{a}}$ & $35.13^{\mathrm{a}}$ \\
$2.25 \times$ & $15.33^{\mathrm{b}}$ & $31.96^{\mathrm{a}}$ & $18.90^{\mathrm{a}}$ & $35.25^{\mathrm{a}}$ \\
$3.00 \times$ & $12.81^{\mathrm{c}}$ & $33.41^{\mathrm{a}}$ & $18.68^{\mathrm{a}}$ & $34.88^{\mathrm{a}}$ \\
$\mathrm{SE}$ & 0.08 & 0.98 & 0.79 & 0.36 \\
$\mathrm{R}^{2}$ & $>0.99$ & 0.42 & 0.70 & 0.45 \\
\hline
\end{tabular}

${ }^{\mathrm{ac}}$ Means within a column not sharing a common superscript are different $(P<0.05)$.

${ }^{1}$ Milk permeate flux $=$ average permeate flux during processing of skim milk $($ time $=90 \mathrm{~min})$.

${ }^{2}$ Starting water flux before milk $=$ water flux of clean membrane before processing.

${ }^{3}$ Fouled water flux $=$ water flux of membrane after processing.

${ }^{4}$ Ending water flux after cleaning $=$ water flux measured after cleaning of the membrane. 


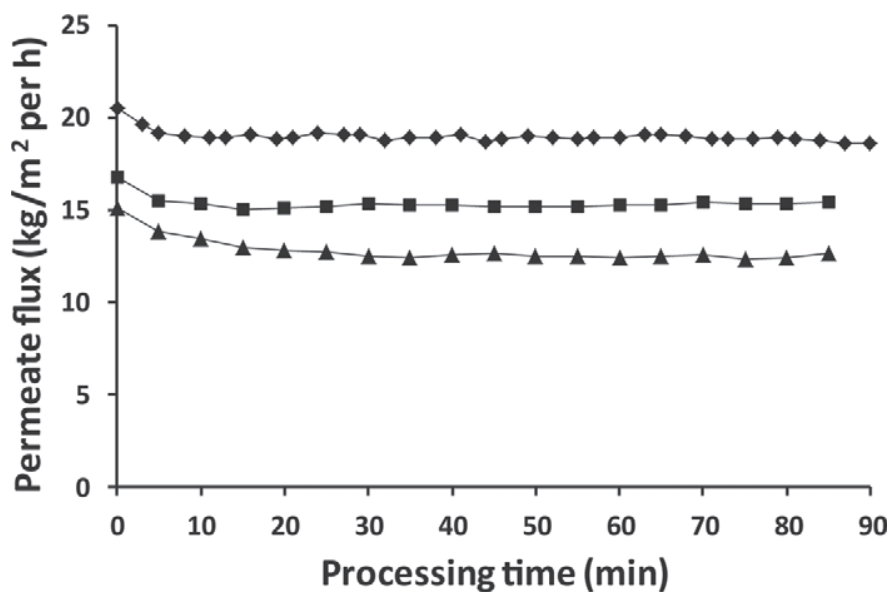

Figure 2. Average $(\mathrm{n}=3)$ permeate flux $\left(\mathrm{kg} / \mathrm{m}^{2}\right.$ per hour $)$ during spiral-wound polyvinylidene fluoride microfiltration of skim milk $\left(50^{\circ} \mathrm{C}\right)$ using 3 concentration factors: $1.50 \times(\checkmark), 2.25 \times(\boldsymbol{\square})$, and $3.00 \times$ $(\mathbf{\Lambda})$.

Degree of fouling $=1-\left(\frac{\text { fouled water flux }}{\text { clean membrane water flux }}\right) \times 100 \%$

and is only reversed by cleaning (degree of fouling of $100 \%=$ total blockage); it was in the range of 40 to $46 \%$ in this study (average $=44.2 \pm 2.2 \%$ ), which is lower than the $80 \%$ reported by Beckman et al. (2010), using the same system and membrane. The only difference in the membrane system between the current study (at $3.00 \times \mathrm{CF}$ ) and the previous study by Beckman et al. (2010) was a slower recirculation rate (164 vs. 238 $\mathrm{kg} / \mathrm{min})$, lower retentate removal rate $(2.1$ vs. $2.8 \mathrm{~kg} /$ min), and a smaller difference between the membrane inlet and outlet pressures (30 vs. $65 \mathrm{kPa}$ ), all caused by the smaller diameter piping in the recirculation loop used in this study. This resulted in a lower TMP in the current study (TMP inlet: 116 vs. $132 \mathrm{kPa}$ ) and apparently less hydraulic resistance due to the deposited foulant layer. A lower fouled water flux indicates more hydraulic resistance due to fouling of the membrane, which is caused by protein-protein and protein-polymer interaction with the membrane (James et al., 2003). Adsorption of protein to hydrophobic polymeric membranes occurs rapidly on contact of milk with the membrane, and it occurs without any TMP (Tong et al., 1988; Rudan, 1990; Bowen and Gan, 1991). The higher fouled water fluxes observed in this experiment (Table 2) compared with Beckman et al. (2010), result from decreased fouling that can only be removed by cleaning the membrane. The lower degree of fouling observed in the present study compared with that in Beckman et al. (2010) may be due to differences in system start up procedures, different feed material compositions, lower
TMP at the inlet, or a combination of these. Less fouling in polymeric PVDF membranes due to lower TMP has been reported (Grandison et al., 2000). As stated above, decreased differences between $\mathrm{Rp}_{\mathrm{i}}$ and $\mathrm{Rp} \mathrm{p}_{\mathrm{o}}$ (i.e., decreased TMP over the length of the membrane) were caused by the constriction in the retentate recirculation pipe, which was not done in the previous studies on our system.

\section{Composition}

Skim Milk. Average (n=3) composition of pasteurized $\left(72.5 \pm 0.1^{\circ} \mathrm{C}, 16 \mathrm{~s}\right)$ skim milk used in this experiment is in Table 3. The skim composition is similar to the skim used by Beckman et al. (2010) and Hurt et al. (2010). Casein as a percentage of TP (CN\% TP) in skim milk was lower in this experiment (Table 3), than was reported by Beckman et al. (2010). The lower CN\%TP in this experiment was caused by the lower pasteurization temperature $\left(72.5^{\circ} \mathrm{C}\right.$ for $16 \mathrm{~s}$ vs. $79^{\circ} \mathrm{C}$ for $19 \mathrm{~s}$, respectively) in the current study than in the previous study (Beckman et al., 2010). Pasteurization of skim milk can lead to disulfide bonding between SP and CN micelles (Sawyer, 1969) and a subsequent increase in the apparent CN\%TP as determined by Kjeldahl analysis (Lynch et al., 1998). If SP becomes bound to CN, a decrease in SP removal from skim milk would be observed as described by Hurt and Barbano, (2010). In the present study, we used a pasteurization temperature very close to minimum $\left(72.5^{\circ} \mathrm{C}\right.$ for $\left.16 \mathrm{~s}\right)$ pasteurization conditions (FDA, 2011) to minimize SP bonding to $\mathrm{CN}$.

Retentate. The mean $(\mathrm{n}=3)$ composition of composite retentates produced during skim milk $\mathrm{MF}\left(50^{\circ} \mathrm{C}\right)$ at $3 \mathrm{CF}$ are shown in Table 4 . Total solids, fat, TN, TP, $\mathrm{CN}$, SP, and CN\%TP increased $(P<0.05)$ with increasing CF (Table 4). Lactose was the only component that decreased $(P<0.05)$ with increasing CF (Table 4$)$. A decrease in lactose in retentate with increasing $\mathrm{CF}$ was expected as the CF increased from 1.50 to $3.00 \times$ due the displacement effect of the increase in concentration of protein and bound minerals. Fat and $\mathrm{CN}$ in the retentate were expected to increase with increasing $\mathrm{CF}$ because fat globules and $\mathrm{CN}$ micelles are rejected by the $0.3-\mu \mathrm{m}$-pore-size membrane. Total solids in retentates were expected to increase with increasing $\mathrm{CF}$ due to the increasing protein and fat content as CF increased (Table 4). Serum protein in retentate was expected to increase with increasing $\mathrm{CF}$ because some $\mathrm{SP}$ was being rejected by the membrane, as reported previously using this same system (Zulewska et al., 2009; Beckman et al., 2010). The increasing TP as a function of CF can be seen in Figure 3. Even after 40 min of system startup and stabilization, protein content (Figure 3 ) in $3.00 \times$ 
Table 3. Mean ( $\mathrm{n}=3$ ) composition (\% by weight) of the pasteurized skim milk

\begin{tabular}{|c|c|c|c|c|c|c|c|c|c|c|}
\hline Item & \multicolumn{10}{|c|}{ Composition $^{1}$} \\
\hline $\mathrm{SE}$ & 0.02 & 0.004 & 0.02 & 0.01 & 0.01 & 0.01 & 0.01 & 0.01 & 0.003 & 0.13 \\
\hline
\end{tabular}

${ }^{1}$ Lactose $=$ anhydrous lactose content measured by infrared spectroscopy; fat $=$ fat content measured by ether extraction; TN $=$ total nitrogen $\times 6.38 ; \mathrm{NCN}=$ noncasein nitrogen $\times 6.38 ; \mathrm{NPN}=\mathrm{NPN} \times 6.38 ; \mathrm{TP}=$ true protein $(\mathrm{TN}-\mathrm{NPN}) ; \mathrm{CN}=\mathrm{TN}-\mathrm{NCN} ;$ serum proteins $=\mathrm{TP}-$ $\mathrm{CN} ; \mathrm{CN} \% \mathrm{TP}=\mathrm{CN}$ as a percentage of $\mathrm{TP}$.

retentate did not reach steady state until approximately $30 \mathrm{~min}$ into steady-state processing (70 min total), which agrees with the previous report by Beckman et al. (2010) for skim milk MF at $3.00 \times$ concentration. It was approximately 0 and $10 \mathrm{~min}$ of processing during the steady-state phase at 1.50 and $2.25 \times$ concentration, respectively, for the retentate to reach consistent TP content (Figure 3). Protein in the retentate at 1.50, 2.25 , and $3.00 \times \mathrm{CF}$ reached maximum values at the end of the steady-state phase of $4.57,6.48$, and $8.01 \%$ (Figure 3), respectively, and were 98, 92, and $86 \%$ of the expected TP in the retentate at 1.50, 2.25, and $3.00 \times \mathrm{CF}$, respectively. The $\mathrm{CN} \% \mathrm{TP}$ increased $(P<$ 0.05) with increasing CF (Table 4). A higher CN\%TP with increasing $\mathrm{CF}$ was expected because as $\mathrm{CF}$ increases, there is more removal of SP. No difference in the NPN content of retentates was detected $(P<0.05)$ among CF.

Permeate. The mean $(\mathrm{n}=3)$ composition of composite permeates produced during skim milk MF $\left(50^{\circ} \mathrm{C}\right)$ at $3 \mathrm{CF}$ are shown in Table 5 . In permeates, TS, TN, NCN, TP, and SP concentrations increased $(P<0.05)$ with increasing $\mathrm{CF}$ (Table 5$)$. No differences in lactose, fat, NPN, and CN concentrations, or CN\%TP were detected $(P>0.05)$ among composite permeates produced at the 3 different CF (Table 5). The composition of $3.00 \times$ permeate was similar to the composition of $3.00 \times$ MF permeate from skim milk created by Zulewska et al. (2009) and Beckman et al. (2010) using the same SW membrane system. Fat contents of permeates were low (Table 5) due to the inability of fat globules to pass through the membrane. If no rejection of lactose or SP were to occur by the membrane, then we would expect both lactose and SP concentration in permeate to remain constant with increasing $\mathrm{CF}$, and the expected concentration of SP in the MF permeate would be slightly higher than the SP concentration in the original skim milk (Table 3; i.e., $0.59 \%$ ), as calculated from the $\mathrm{SP}$ in the permeate portion. In previous work with ceramic membranes (Zulewska et al., 2009; Hurt et al., 2010), the SP concentration in the MF permeate was very close to this theoretical value. This was not the case in the present study; the concentrations of SP in the MF permeate at all CF (Table 5) were well below theoretical values (Hurt and Barbano, 2010). However, lactose, but not SP concentration, in the permeate remained constant among the $3 \mathrm{CF}$ used (Table 5). The increase in SP in the permeate with increasing $\mathrm{CF}$ could be caused by a lower rejection of SP by the foulant layer at different $\mathrm{CF}$ due to a difference in the porosity of the foulant layer. Zulewska and Barbano (2013) reported that little rejection of SP occurred by the same PVDF membrane as used in our system if MF permeate produced with a ceramic membrane system was MF with the PVDF membrane starting from a clean membrane without

Table 4. Mean $(\mathrm{n}=3)$ composition of composite retentates (\% by weight) by concentration factor (CF) during microfiltration of skim milk $\left(50^{\circ} \mathrm{C}\right)$ using a $0.3-\mu \mathrm{m}$ spiral-wound polyvinylidene fluoride membrane

\begin{tabular}{|c|c|c|c|c|c|c|c|c|c|c|}
\hline $\mathrm{CF}$ & \multicolumn{10}{|c|}{ Composition $^{1}$} \\
\hline $2.25 \times$ & $12.56^{\mathrm{b}}$ & $4.57^{\mathrm{b}}$ & $0.21^{\mathrm{b}}$ & $6.51^{\mathrm{b}}$ & $1.16^{\mathrm{a}}$ & $0.170^{\mathrm{a}}$ & $6.34^{\mathrm{b}}$ & $5.35^{\mathrm{b}}$ & $0.99^{\mathrm{b}}$ & $84.42^{\mathrm{b}}$ \\
\hline $3.00 \times$ & $14.06^{\mathrm{a}}$ & $4.47^{\mathrm{c}}$ & $0.26^{\mathrm{a}}$ & $7.87^{\mathrm{a}}$ & $1.20^{\mathrm{a}}$ & $0.166^{\mathrm{a}}$ & $7.71^{\mathrm{a}}$ & $6.67^{\mathrm{a}}$ & $1.03^{\mathrm{a}}$ & $86.58^{\mathrm{a}}$ \\
\hline SE & 0.03 & 0.003 & 0.01 & 0.01 & 0.01 & 0.003 & 0.02 & 0.02 & 0.01 & 0.19 \\
\hline
\end{tabular}

${ }^{\mathrm{a}-\mathrm{c}}$ Means within a column not sharing a common superscript are different $(P<0.05)$.

${ }^{1}$ Lactose $=$ anhydrous lactose measured by infrared spectroscopy; fat $=$ fat content measured by ether extraction; TN $=$ total nitrogen $\times 6.38$; $\mathrm{NCN}=$ noncasein nitrogen $\times 6.38 ; \mathrm{NPN}=\mathrm{NPN} \times 6.38 ; \mathrm{TP}=$ true protein $(\mathrm{TN}-\mathrm{NPN}) ; \mathrm{CN}=\mathrm{TN}-\mathrm{NCN} ;$ serum proteins $=\mathrm{TP}-\mathrm{CN}$; $\mathrm{CN} \% \mathrm{TP}=$ casein as a percentage of $\mathrm{TP}$. 
Table 5. Mean $(\mathrm{n}=3)$ composition of composite permeates (\% by weight) by concentration factor (CF) during microfiltration of skim milk $\left(50^{\circ} \mathrm{C}\right)$ using a $0.3-\mu \mathrm{m}$ spiral-wound polyvinylidene fluoride membrane

\begin{tabular}{|c|c|c|c|c|c|c|c|c|c|c|}
\hline \multirow[b]{2}{*}{$\mathrm{CF}$} & \multicolumn{10}{|c|}{ Composition $^{1}$} \\
\hline & $\mathrm{TS}$ & Lactose & Fat & $\mathrm{TN}$ & $\mathrm{NCN}$ & $\mathrm{NPN}$ & $\mathrm{TP}$ & $\mathrm{CN}$ & $\begin{array}{l}\text { Serum } \\
\text { proteins }\end{array}$ & $\mathrm{CN} \% \mathrm{TP}$ \\
\hline $2.25 \times$ & $6.14^{\mathrm{b}}$ & $4.90^{\mathrm{a}}$ & $0.0012^{\mathrm{a}}$ & $0.44^{\mathrm{b}}$ & $0.44^{\mathrm{b}}$ & $0.176^{\mathrm{a}}$ & $0.27^{\mathrm{b}}$ & $0.007^{\mathrm{a}}$ & $0.26^{\mathrm{b}}$ & $2.60^{\mathrm{a}}$ \\
\hline $3.00 \times$ & $6.19^{\mathrm{a}}$ & $4.90^{\mathrm{a}}$ & $0.0005^{\mathrm{a}}$ & $0.51^{\mathrm{a}}$ & $0.49^{\mathrm{a}}$ & $0.172^{\mathrm{a}}$ & $0.33^{\mathrm{a}}$ & $0.015^{\mathrm{a}}$ & $0.32^{\mathrm{a}}$ & $4.44^{\mathrm{a}}$ \\
\hline $\mathrm{SE}$ & 0.005 & 0.005 & 0.0008 & 0.003 & 0.003 & 0.007 & 0.006 & 0.004 & 0.008 & 1.51 \\
\hline
\end{tabular}

${ }^{\mathrm{a}-\mathrm{C}}$ Means within a column not sharing a common superscript are different $(P<0.05)$.

${ }^{1}$ Lactose $=$ anhydrous lactose measured by infrared spectroscopy; fat $=$ fat content measured by ether extraction; TN $=$ total nitrogen $\times 6.38$ $\mathrm{NCN}=$ noncasein nitrogen $\times 6.38 ; \mathrm{NPN}=\mathrm{NPN} \times 6.38 ; \mathrm{TP}=$ true protein $(\mathrm{TN}-\mathrm{NPN}) ; \mathrm{CN}=\mathrm{TN}-\mathrm{NCN}$; serum proteins $=\mathrm{TP}-\mathrm{CN}$; $\mathrm{CN} \% \mathrm{TP}=$ casein as a percentage of $\mathrm{TP}$.

any fouling of the membrane by skim milk. An increase in SP concentration in the permeate (i.e., less rejection of SP passage) with increasing CF (Table 5) indicated that (1) SP rejection by the foulant layer decreased with increasing $\mathrm{CF}$, (2) SP rejection by the membrane decreased with increasing $\mathrm{CF}$, or (3) SP rejection by the membrane and foulant layer did not change with $\mathrm{CF}$, but the concentration of SP near the surface of the membrane increased with increasing $\mathrm{CF}$ due to SP rejection, producing a higher concentration of SP in the permeate portion of the recirculating retentate, allowing more SP to permeate the membrane. A higher CF during skim milk MF was expected to lead to more concentration polarization fouling near the surface of the membrane, which might be expected to decrease fouled water flux and increase SP rejection. This was not the case. As shown in Table 2, no difference $(P>$ 0.05 ) between the fouled water flux was detected among the $3 \mathrm{CF}$, indicating that the resistance to water flow

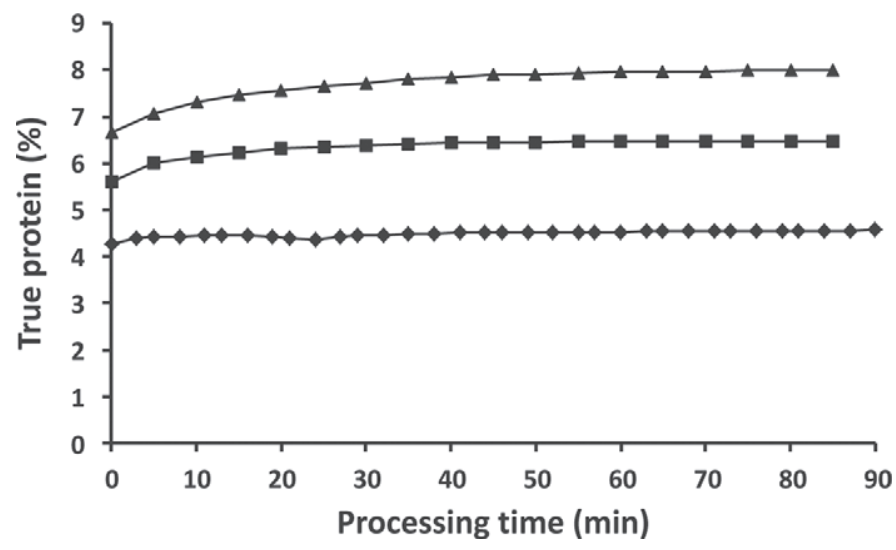

Figure 3. Average $(\mathrm{n}=3)$ true protein content $(\%)$ in the retentate during spiral-wound polyvinylidene fluoride microfiltration of skim milk $\left(50^{\circ} \mathrm{C}\right)$ using 3 concentration factors: $1.50 \times(\diamond), 2.25 \times(\mathbf{\square})$, and $3.00 \times(\mathbf{\Lambda})$. True protein content was measured by infrared spectroscopy. through the membrane by the combination of the membrane and the foulant layer that can only be removed by cleaning was not different among the 3 different $\mathrm{CF}$. However, passage of SP through the membrane plus foulant layer increased with increasing $\mathrm{CF}$, as reflected by the increase in SP in the MF permeate with increasing CF (Table 5). If the higher concentration of SP in the MF permeate with increasing CF was solely due to the higher concentration of SP in the retentate in the recirculation loop, then one would not expect the percentage removal of SP from the original skim milk to differ among CF. This point will be addressed later in the section of the discussion on SP removal.

Casein contents of the composite permeates were low for all CF (Table 5), which was supported by the color analysis of the permeates, which detected no difference $(P<0.05)$ in $\mathrm{L}$ values (lightness/opacity; $20.31 \pm 0.03$, $20.66 \pm 0.21$, and $20.52 \pm 0.08$, among 1.50, 2.25, and $3.00 \times$ permeates, respectively). The concentration of $\mathrm{TP}(\%)$ in permeates at $1.50,2.25$, and $3.00 \times \mathrm{CF}$ for the 90 -min duration of the steady-state phase of MF is shown in Figure 4. From 10 to 90 min during steadystate processing, protein in permeate at $1.50,2.25$, and $3.00 \times \mathrm{CF}$, decreased $(P<0.05) 0.022,0.034$, and $0.035 \%$ per hour, respectively (Figure 4 ). Decreasing protein concentration in permeate during $\mathrm{MF}$ at all $\mathrm{CF}$ can be attributed to the fouling of the SW MF membrane due to concentration polarization-driven fouling, which progressively blocked SP passage into permeate with time at all $\mathrm{CF}$.

\section{SP Removal}

Determination of the effect of CF on SP removal from skim milk was a focus of this research. The quantity of skim milk that was MF, the percentage SP removal from skim milk, and the rate $\left(\mathrm{kg} / \mathrm{m}^{2}\right.$ per hour) of SP removal from skim milk at each of the $3 \mathrm{CF}$ are shown in Table 6. The quantity of skim milk used for each CF was cal- 


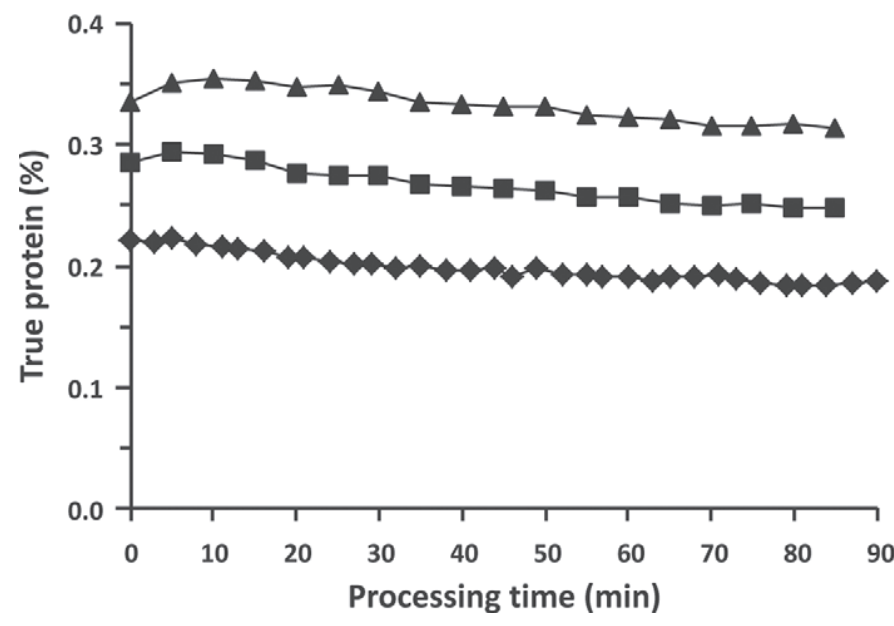

Figure 4. Average $(\mathrm{n}=3)$ true protein content $(\%)$ in the permeate during spiral-wound polyvinylidene fluoride microfiltration of skim milk $\left(50^{\circ} \mathrm{C}\right)$ using 3 concentration factors: $1.50 \times(\checkmark), 2.25 \times(\mathbf{\square})$, and $3.00 \times(\boldsymbol{\Lambda})$. True protein content was measured by infrared spectroscopy.

culated as the sum of permeate $(\mathrm{kg})$ and retentate $(\mathrm{kg})$ collected during the 90-min steady-state phase of MF. As CF increased, the quantity of skim that was MF with same membrane surface area (i.e., $20.5 \mathrm{~m}^{2}$ ) in 90 min decreased by about $68 \%(P<0.05$; Table 6$)$, which was expected due to the lower $(P<0.05)$ removal rates of permeate and retentate with increasing CF (Table 1). For comparison, theoretical percentage SP removals (assuming no resistance to passage of SP through the MF membrane) from skim milk using $\mathrm{MF}$ at the $3 \mathrm{CF}$ are presented in Table 6 , using the approach described by Hurt and Barbano, (2010) to calculate theoretical SP removal at different CF. Zulewska et al. (2009) and Beckman et al. (2010) reported SP removals using $3.00 \times \mathrm{CF}$ MF (with SW membranes) of skim of 38.6 and $38.6 \%$, respectively, which are similar to the value of $35.6 \%$ at $3.00 \times \mathrm{CF}$ in the present study (Table 6 ).
The observed percentage SP removal from skim milk decreased $(P<0.05)$ from about $36 \%$ to almost $10 \%$ (Table 6) with decreasing $\mathrm{CF}$ under the conditions used in the current study primarily due to the lower SP content in the permeate (Table 5). We observed increased flux $(P<0.05)$ at lower CF (Table 2), but SP removal as a percentage of theoretical SP removal unexpectedly decreased with decreasing CF (Table 6) due to a lower $\mathrm{SP}$ concentration in the permeate at lower CF (Table $5)$. The percentage of theoretical SP removal increased $(P<0.05)$ with increasing CF (Table 6). What could have caused this unexpected decrease in SP removal at lower CF? We hypothesize that the structure of the concentration polarization-driven foulant layer may be different or the interaction of the foulant layer with the membrane structure may be different depending on the conditions near the membrane during the formation of the foulant layer at startup.

No difference in the rate of SP removal $\left(\mathrm{kg} / \mathrm{m}^{2}\right.$ per hour) from skim milk was detected $(P>0.05)$ among $\mathrm{CF}$ (Table 6). It is interesting that a constant amount of SP passed through the membrane (per $\mathrm{m}^{2}$ per hour), whereas the amount of water passing through the membrane (per $\mathrm{m}^{2}$ per hour) increased with decreasing CF. Thus, resistance to passage of water decreased with decreasing $\mathrm{CF}$, but the SP removal increased with increasing $\mathrm{CF}$, indicating that the rejection characteristics of the foulant layer formed at different $\mathrm{CF}$ was different. The SP removal rate at all $3 \mathrm{CF}$ used (Table 6) were similar to the SP removal rate found by Beckman et al. (2010; $0.05 \mathrm{~kg} / \mathrm{m}^{2}$ per hour) for a $3.00 \times \mathrm{CF}$ skim milk $\left(50^{\circ} \mathrm{C}\right) \mathrm{MF}$ with $\mathrm{SW}$ membranes.

\section{Membrane Foulant Role in SP Removal}

Foulant Composition. Bovine milk contains fat, protein, lactose, minerals (e.g., calcium and phosphate), and other minor constituents. During membrane MF of

Table 6. Mean $(\mathrm{n}=3)$ quantity of skim milk used, percentage serum protein (SP) removed from skim milk, and SP removal rate during the steady-state phase for a spiral-wound polymeric polyvinylidene fluoride membrane microfiltration $(0.3 \mu \mathrm{m})$ of skim milk at 3 concentration factors $(\mathrm{CF})$

\begin{tabular}{lccccc}
\hline CF & $\begin{array}{c}\text { Skim milk } \\
(\mathrm{kg})\end{array}$ & $\begin{array}{c}\text { Theoretical SP } \\
\text { removal }^{2}(\%)\end{array}$ & $\begin{array}{c}\text { Skim SP } \\
\text { removed }(\%)\end{array}$ & $\begin{array}{c}\text { Percentage of } \\
\text { theoretical SP }^{\text {removal }^{3}(\%)}\end{array}$ & $\begin{array}{c}\text { SP removal rate } \\
\left(\mathrm{kg} / \mathrm{m}^{2} \text { per hour }\right)\end{array}$ \\
\hline $1.50 \times$ & $1,774.0^{\mathrm{a}}$ & 34.4 & $10.56^{\mathrm{c}}$ & $30.69^{\mathrm{c}}$ & $0.036^{\mathrm{a}}$ \\
$2.25 \times$ & $836.5^{\mathrm{b}}$ & 57.3 & $24.33^{\mathrm{b}}$ & $42.42^{\mathrm{b}}$ & $0.039^{\mathrm{a}}$ \\
$3.00 \times$ & $572.6^{\mathrm{c}}$ & 68.8 & $35.57^{\mathrm{a}}$ & $51.70^{\mathrm{a}}$ & $0.039^{\mathrm{a}}$ \\
$\mathrm{SE}$ & 8.2 & & 0.79 & 1.30 & 0.001 \\
$\mathrm{R}^{2}$ & $>0.99$ & & 0.99 & 0.97 & 0.51 \\
\hline
\end{tabular}

${ }^{\mathrm{a}-\mathrm{c}}$ Means within a column not sharing a common superscript are different $(P<0.05)$.

${ }^{1}$ Skim milk $(\mathrm{kg})=$ permeate $(\mathrm{kg})+$ retentate $(\mathrm{kg})$ collected during a 90-min collection.

${ }^{2}$ Theoretical SP removal calculated as in Hurt and Barbano (2010).

${ }^{3}$ Percentage of theoretical SP removal = average skim milk SP removed at each CF divided by theoretical SP removal. 
skim milk, the primary membrane foulants are proteins and milk minerals (Cheryan, 1998). The hydrophilicity of the membrane material is an important consideration when microfiltering solutions with proteins (Rudan, 1990; Cheryan, 1998), as hydrophobic organic membranes, including PVDF, have been known to be rapidly fouled by adsorbed hydrophobic proteins (Tong et al., 1988; Bowen and Gan, 1991). The adsorption of proteins onto the membrane can account for a significant portion of the reduction in flux (van der Horst, 1995; James et al., 2003). In addition to protein adsorption onto membranes, CN micelles may also become lodged in the MF membrane pores, effectively blocking passage of permeate through that pore (Attia et al., 1991). Casein has been demonstrated to be the primary foulant during MF (with SW membranes) of skim milk that restricts passage of SP through a PVDF membrane (Zulewska and Barbano, 2013). We have observed in our experiments with $\mathrm{MF}$ skim at $50^{\circ} \mathrm{C}$ using $0.3-\mu \mathrm{m}$-poresize SW PVDF MF membranes (Zulewska et al., 2009; Beckman et al., 2010; Zulewska and Barbano, 2013), including the current experiment during the startupstabilization phase (data not reported), that during the first 5 to $10 \mathrm{~min}$ of filtration, the permeate exiting the system is opaque and white in color. This means that CN micelles are passing through the membrane. After 5 min of skim milk MF, the permeate becomes clear, which indicates that $\mathrm{CN}$ micelles are passing through the membrane plus foulant until the effective pore size decreases and rejects the passage of CN micelles. Protein interaction with the membrane through adsorption and through pore blocking may account for a significant portion of the initial flux decline and increased rejection of SP seen in skim milk MF using SW polymeric membranes (Zulewska et al., 2009; Beckman et al., 2010). Zulewska and Barbano (2013) demonstrated that when $\mathrm{CN}$-free skim milk (i.e., permeate from MF) was MF using an SW polymeric PVDF membrane, little decrease in hydraulic resistance of the membrane and little rejection of SP occurred, indicating that $\mathrm{CN}$ was the important foulant, causing SP rejection during MF of skim milk using PVDF MF membranes at $50^{\circ} \mathrm{C}$ to process skim milk.

Formation and Progression of Fouling. Interaction of milk components with an SW polymeric MF membrane surface is thought to occur in a series of steps. Description of the progression of fouling during MF of skim milk using hydrophobic SW polymeric membranes has been discussed previously (Marshall and Daufin, 1995; Lawrence et al., 2008; Zulewska and Barbano, 2013). From the data in the current experiment and the data from Zulewska et al. (2009), Beckman et al. (2010), and Zulewska and Barbano (2013), we believe a good model to describe fouling during polymeric SW skim MF is the "resistance-in-series" model (Suki et al., 1984; van der Horst, 1995), as shown below:

$$
J=\frac{\mathrm{TMP}}{\left(R_{M}+R_{A}+R_{P}+R_{G}+R_{C P}\right)},
$$

where $J$ = permeate flux, $R_{M}=$ resistance due to the membrane, $R_{A}=$ resistance due to adsorption, $R_{P}=$ resistance due to pore blocking, $R_{G}=$ resistance due to precipitation or gel-layer formation, and $R_{C P}=$ resistance due to concentration polarization. This model is used to describe flux decline in a membrane as a function of the total membrane resistance applied by the individual factors. This same thinking can be used when considering the rejection characteristics of the foulant, but the rejection characteristics may or may not be directly correlated with the change in flux.

In our study, the TMP at the inlet and outlet of the membrane were the same among CF (Table 1), and the resistance of the clean membrane $\left(R_{M}\right)$ did not change among CF (Table 2). As discussed earlier, protein adsorption $\left(R_{A}\right)$ and $\mathrm{CN}$ infiltration into the membrane pores $\left(R_{P}\right)$ occurred early in the MF of skim milk and likely accounted for the majority of fouling during the first few minutes of MF when the permeate changed in appearance from white to clear and the difference in SP rejection among different CF was created. During the remainder of the 40 min start-up phase of this experiment, these factors (TMP, $R_{M}, R_{A}$, and $R_{P}$ ) remained constant or changed very little, whereas the $R_{G}$ was mostly developed before steady-state processing began. Any further resistance caused by concentration polarization $\left(R_{C P}\right)$ continued to progress during the steady-state phase. A secondary effect of concentration polarization is the accumulation of retained feed solids at the surface of the membrane during the steady-state phase of processing, causing the formation of a gel layer $\left(R_{G}\right)$, which produced the gradual decline $(P<0.05)$ in flux at $3.00 \times \mathrm{CF}$ with time (shown in Figure 2). As concentration polarization increases during MF of skim milk with SW membranes, so too should $R_{G}$.

To help describe how the initial deposition of foulants may affect SP removal during MF, a diagram is presented as Figure 5. The SW MF system was started similarly at each CF. However, after the permeate exit valve was opened to allow passage of water and solutes through the MF membrane, the magnitude of restriction of the retentate bleed valve differed among $\mathrm{CF}$. The difference in restriction in retentate removal may have influenced the interaction of milk constituents with the MF membrane, as shown in Figure 5. To achieve a low retentate removal rate at $\mathrm{CF} 3.00 \times$ (Table 1 ), the retentate removal valve was closed over about a 5 -min 


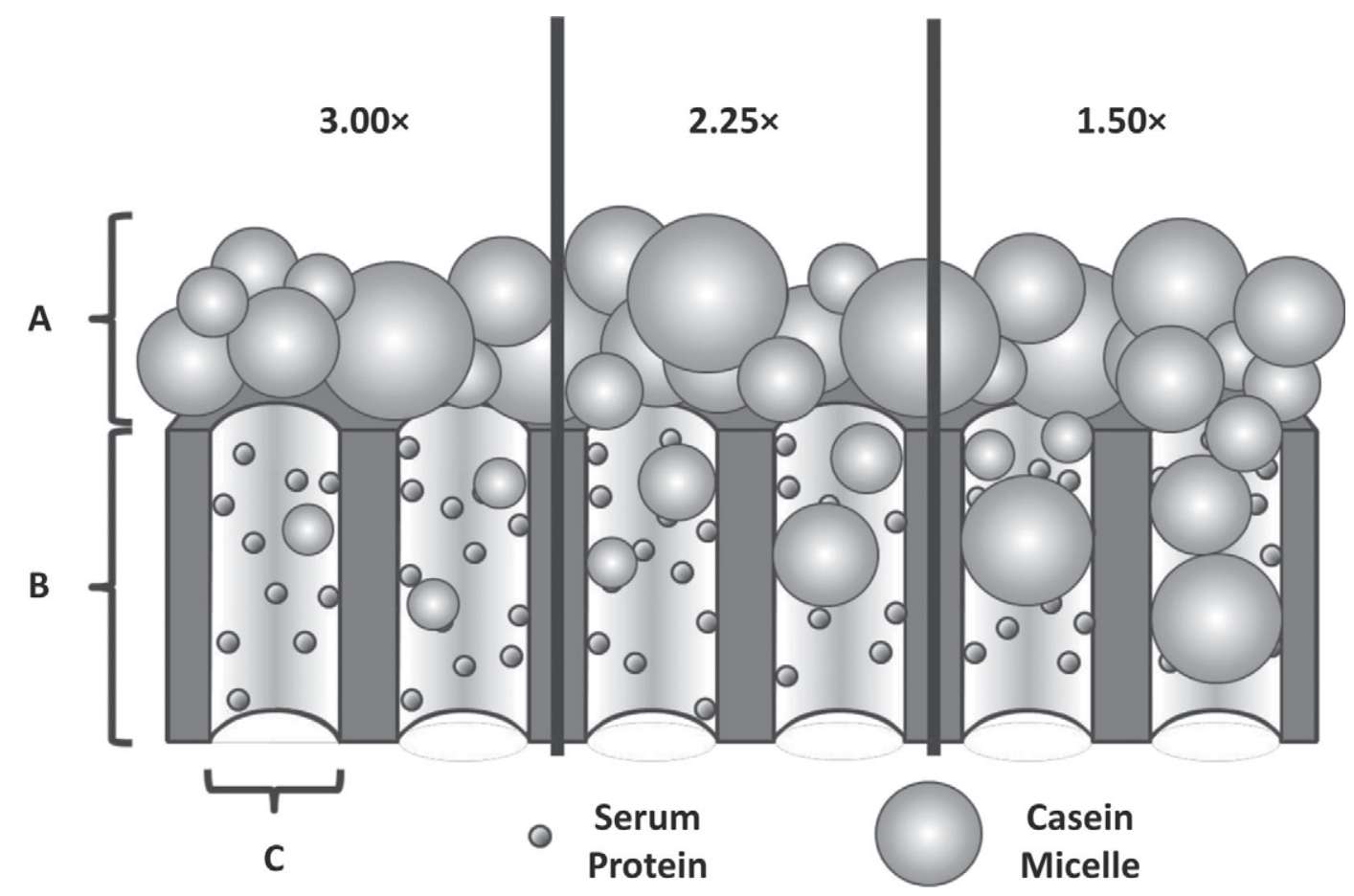

Figure 5. The hypothesized fouling of a spiral-wound polymeric microfiltration membrane (0.3- $\mu \mathrm{m}$ pore size) at 3 concentration factors $(1.50,2.25$, and $3.00 \times)$ by skim milk at $50^{\circ} \mathrm{C}$. Casein micelles have formed a gel layer $(\mathrm{A})$ on the retentate side of the membrane $(\mathrm{B})$ and serum proteins are adhered onto the interior of the membrane pore $(\mathrm{C})$.

period until the correct $\mathrm{CF}$ was achieved. At CF $3.00 \times$, the increased back pressure on the retentate side of the membrane caused by rapid closing of the retentate removal valve caused a decrease in retentate recirculation flow (Table 1). Low recirculation rate, and a rapid increase in large rejected solutes (i.e., $\mathrm{CN}$ micelles) at high CF (e.g., 3.00×; Table 4) caused a rapid formation of the concentration polarization $\left(R_{G}\right.$ and $\left.R_{C P}\right)$ gel layer (Figure 5) with minimal time for $\mathrm{CN}$ micelle infiltration into the pores of the membrane to cause pore blocking $\left(R_{P}\right)$. It is likely that adsorption $\left(R_{P}\right)$ of small SP was occurring within the pores but had little effect on overall hydraulic resistance or SP rejection (Figure 5). In contrast, at $\mathrm{CF} 1.50 \times$, the retentate removal valve was not closed as completely or as quickly (15-min duration) as at $\mathrm{CF} 3.00 \times$, the retentate removal rate was 6 times faster than at CF $3.00 \times(13.2$ vs. $2.1 \mathrm{~kg} /$ $\mathrm{min}$ ), the recirculation rate was faster (Table 1 ), and the concentration of rejected solutes (i.e., $\mathrm{CN}$ micelles) were lower (Table 4) than at CF $3.00 \times$, which would favor less concentration polarization gel layer formation (i.e., lower $R_{G}$ and $R_{C P}$ ) and allow more time for pore blocking $\left(R_{P}\right)$ and increased extent of pore blocking by $\mathrm{CN}$ micelles at $\mathrm{CF} 1.50 \times$ compared with the conditions at $\mathrm{CF} 3.00 \times$. Thus, we hypothesize that a greater opportunity existed for $\mathrm{CN}$ micelles to become lodged in the membrane pores (Figure 5), producing a higher
$R_{P}$ at $1.50 \times$ than at $3.00 \times$ concentration, effectively reducing the effective pore size and causing a difference in SP rejection among CF. We hypothesize that differences in pore plugging $\left(R_{P}\right)$ among $\mathrm{CF}$ in the first few minutes of operation may cause relatively large differences in SP rejection by the membrane without causing the same magnitude of differences in hydraulic resistance. Thus, we feel that increased pore plugging at low $\mathrm{CF}$ increased the rejection of SP and lowered the removal of SP from skim milk (Table 6).

Improving SP Removal with Polymeric Membranes. Zulewska and Barbano (2013) demonstrated that a $0.3-\mu \mathrm{m}$ SW PVDF MF membrane provides little resistance to passage of SP into permeate and that the $\mathrm{CN}$ foulant and the characteristics of that foulant were the determinant of SP removal from skim milk during $\mathrm{MF}$ at $50^{\circ} \mathrm{C}$. Future studies should focus on controlling the series of events in the formation of the resistances to passage of solutes through the membrane pores, not just the resistance to passage of solvent. For example, a strategy of using a smaller membrane pore size in combination with rapidly building the gel layer could actually improve the passage of SP through the combination of membrane plus foulant without having much influence on overall solvent flux. The rapid formation of the gel layer and minimization of pore plugging might be achieved by starting the MF system with a small 
volume of more concentrated feed solution (i.e., 3.00× MF retentate that is low in SP content from the previous day) at start up to transition from water to product to fill the system and then continue to run the concentrated milk in complete recycle for a few minutes at $1.50 \times$ to achieve the rapid formation of a gel layer (that will reject $\mathrm{CN}$ but allow SP to pass) while minimizing pore blocking that may have a larger impact on SP rejection. Once the gel layer is established, then skim milk would be fed into the MF system to flush out the $3.00 \times \mathrm{MF}$ retentate and the process would continue the MF skim milk at CF $1.50 \times$.

\section{CONCLUSIONS}

Permeate flux was increased $(12.8,15.3$, and $19.0 \mathrm{~kg} /$ $\mathrm{m}^{2}$ per hour) with decreasing $\mathrm{CF}$ from 3.00 to $1.50 \times$, whereas fouled water flux did not differ among CF, indicating that the effect of membrane fouling on hydraulic resistance of the membrane was similar at all $\mathrm{CF}$. However, the $\mathrm{CF}$ used when MF skim milk $\left(50^{\circ} \mathrm{C}\right)$ with a $0.3-\mu \mathrm{m}$ SW polymeric PVDF membrane did affect the percentage of SP removed. As CF increased, from 1.50 to $3.00 \times$, the percentage of SP removed from skim milk increased from 10.56 to $35.57 \%$ in a single-stage bleed-and-feed MF system. Rejection of SP during MF of skim milk with SW PVDF membranes was caused by fouling of the membrane, not by the membrane itself and differences in the foulant characteristic among CF influenced SP rejection more than it influenced hydraulic resistance. We hypothesize that differences in the conditions near the surface of the membrane and within the pores during the first few minutes of processing, when $\mathrm{CN}$ micelles pass through the membrane, influenced the rejection of SP protein because more pore size narrowing and plugging occurred at low $\mathrm{CF}$ than at high CF due to a slower rate of gel layer formation at low CF. It is possible that percentage removal of SP from skim milk at $50^{\circ} \mathrm{C}$ could be improved by optimization of the membrane pore size, feed solution composition and concentration, and controlling the rate of formation of concentration polarization-derived gel layer at the surface of the membrane during the first few minutes of processing.

\section{ACKNOWLEDGMENTS}

This project was partially supported by the New York State Milk Promotion Board (Albany, NY) and the Northeast Dairy Foods Research Center (Ithaca, NY). The authors thank the following Cornell University (Ithaca, NY) students and staff members that provided technical support: Michael Adams, Michelle Bilotta, Sara Bova, Chassidy Coon, Emily Hurt, and the staff of the Cornell University Dairy. The input and technical support of Justyna Zulewska from the University of Warmia and Mazury Olsztyn, Poland, is appreciated.

\section{REFERENCES}

Adams, M. C., and D. M. Barbano. 2013. Serum protein removal from skim milk with a 3 -stage, $3 \times$ ceramic Isoflux membrane process at $50^{\circ}$ C. J. Dairy Sci. 96:2020-2034.

AOAC International. 2000. Official Methods of Analysis. 17th ed. AOAC International, Gaithersburg, MD.

Attia, H., M. Bennasar, and B. T. de la Fuente. 1991. Study of the fouling of inorganic membranes by acidified milks using scanning electron microscopy and electrophoresis. II. Membrane with pore diameter $0.8 \mu \mathrm{m}$. J. Dairy Res. 58:51-65.

Beckman, S. L., J. Zulewska, M. Newbold, and D. M. Barbano. 2010. Production efficiency of micellar casein concentrate using polymeric spiral-wound microfiltration membranes. J. Dairy Sci. 93:4506-4517.

Beliciu, C. M., A. Sauer, and C. I. Moraru. 2012. The effect of commercial sterilization regimens on micellar casein concentrates. J. Dairy Sci. 95:5510-5526.

Bowen, W. R., and Q. Gan. 1991. Properties of microfiltration membranes: Adsorption of bovine serum albumin at polyvinylidene fluoride membranes. J. Colloid Interface Sci. 144:254-262.

Brans, G., C. G. P. H. Schroën, R. G. M. van der Sman, and R. M. Boom. 2004. Membrane fractionation of milk: State of the art and challenges. J. Membr. Sci. 243:263-272.

Campbell, R. E., M. C. Adams, M. Drake, and D. M. Barbano. 2013. Effect of bleaching permeate from microfiltered skim milk on $80 \%$ serum protein concentrate. J. Dairy Sci. 96:1387-1400.

Cheryan, M. 1998. Ultrafiltration and Microfiltration Handbook. Technomic Publishing Co. Inc. Lancaster, PA.

Evans, J., J. Zulewska, M. Newbold, M. A. Drake, and D. M. Barbano. 2009. Comparison of composition, sensory, and volatile components of thirty-four percent whey protein and milk serum protein concentrates. J. Dairy Sci. 92:4773-4791.

Evans, J., J. Zulewska, M. Newbold, M. A. Drake, and D. M. Barbano. 2010. Comparison of composition and sensory properties of $80 \%$ whey protein and milk serum protein concentrates. J. Dairy Sci. 93:1824-1843.

FDA (Food and Drug Administration). 2011. Standards for grade "A" milk and milk products. Pages 8-9, 28-30 in Grade "A" Pasteurized Milk Ordinance. Standards for grade "A" milk and milk products. US Department of Health and Human Services, Public Health Service, Washington, DC.

Grandison, A. S., W. Youravong, and M. J. Lewis. 2000. Hydrodynamic factors affecting flux and fouling during ultrafiltration of skimmed milk. Lait 80:165-174.

Hurt, E., and D. M. Barbano. 2010. Processing factors that influence casein and serum protein separation by microfiltration. J. Dairy Sci. 93:4928-4941.

Hurt, E., J. Zulewska, M. Newbold, and D. M. Barbano. 2010. Micellar casein concentrate production with a $3 \times, 3$-stage, uniform transmembrane pressure ceramic membrane process at $50^{\circ} \mathrm{C}$. J. Dairy Sci. 93:5588-5600.

James, B. J., Y. Jing, and X. D. Chen. 2003. Membrane fouling during filtration of milk-A microstructural study. J. Food Eng. 60:431-437.

Jervis, S., R. Campbell, K. L. Wojciechowski, E. A. Foegeding, M. A. Drake, and D. M. Barbano. 2012. Effect of bleaching whey on sensory and functional properties of $80 \%$ whey protein concentrate. J. Dairy Sci. 95:2848-2862.

Kaylegian, K. E., G. E. Houghton, J. M. Lynch, J. R. Fleming, and D. M. Barbano. 2006. Calibration of infrared milk analyzers: Modified milk versus producer milk. J. Dairy Sci. 89:2817-2832.

Lawrence, N. D., S. E. Kentish, A. J. O'Connor, A. R. Barber, and G. W. Stevens. 2008. Microfiltration of skim milk using poly- 
meric membranes for casein manufacture. Separ. Purif. Technol. $60: 237-244$.

Le Berre, O., and G. Daufin. 1996. Skimmilk crossflow microfiltration performance versus permeation flux to wall shear stress ratio. J. Membr. Sci. 117:261-270.

Lynch, J. M., D. M. Barbano, and J. R. Fleming. 1998. Indirect and direct determination of the casein content of milk by Kjeldahl nitrogen analysis: Collaborative study. J. AOAC Int. 81:763-774.

Marshall, A. D., and G. Daufin. 1995. Physico-chemical aspects of membrane fouling by dairy fluids. Pages $8-35$ in Fouling and Cleaning of Pressure Driven Membrane Processes. IDF Special Issue 9504. International Dairy Federation (IDF), Brussels, Belgium.

Maubois, J. L. 1980. Ultrafiltration of whey. Int. J. Dairy Technol. $33: 55-58$.

Nelson, B. K., and D. M. Barbano. 2005. A microfiltration process to maximize removal of serum proteins from skim milk before cheese making. J. Dairy Sci. 88:1891-1900.

Rudan, M. A. 1990. Membrane fouling during ultrafiltration of milk. MS Thesis. Cornell University, Ithaca, NY.

Saboya, L. V., and J.-L. Maubois. 2000. Current developments of microfiltration technology in the dairy industry. Lait 80:541-553.

Sauer, A., and C. I. Moraru. 2012. Heat stability of micellar casein concentrates as affected by temperature and $\mathrm{pH}$. J. Dairy Sci. 95:6339-6350.
Sawyer, W. H. 1969. Complex between $\beta$-lactoglobulin and $\kappa$-casein. A review. J. Dairy Sci. 52:1347-1355.

Suki, A., A. G. Fane, and C. J. D. Fell. 1984. Flux decline in protein ultrafiltration. J. Membr. Sci. 21:269-283.

Tong, P. S., D. M. Barbano, and M. A. Rudan. 1988. Characterization of proteinaceous membrane foulants and flux decline during the early stages of whole milk ultrafiltration. J. Dairy Sci. 71:604-612. van der Horst, H. C. 1995. Fouling of organic membranes during processing of dairy liquids. Pages 36-52 in Fouling and Cleaning of Pressure Driven Membrane Processes. IDF Special Issue 9504. International Dairy Federation (IDF), Brussels, Belgium.

Walstra, P., J. T. Wouters, and T. J. Geurts. 2006. Dairy Science and Technology. 2nd ed. Taylor \& Francis Group. Boca Raton, FL.

Zulewska, J., and D. M. Barbano. 2013. Influence of casein on flux and passage of serum proteins during microfiltration using polymeric spiral-wound membranes at $50^{\circ} \mathrm{C}$. J. Dairy Sci. 96:2048-2060.

Zulewska, J., M. Newbold, and D. M. Barbano. 2009. Efficiency of serum protein removal from skim milk with ceramic and polymeric membranes at $50^{\circ}$ C. J. Dairy Sci. 92:1361-1377. 